\title{
Report on Bioventing of Petroleum Contaminated Soils at 108-3C: Active Extraction and Passive Injection (Barometric Pumping) of a Gaseous Nutrient (U)
}

by

J. R. Kastner

Westinghouse Savannah River Company

Savannah River Site

Aiken, South Carolina 29808

K. Lombard.

J. Radway

J. Santo Domingo

T. C. Hazen

G. L' Burgage

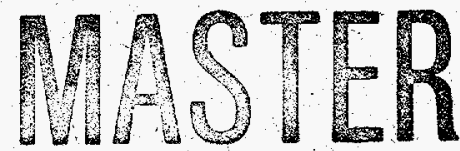

DOE Contract No: DE-AC09-96SR18500

This paper was prepared in connection with work done under the above contract number with the U.S.

Department of Energy. By acceptance of this paper, the publisher and/or recipient acknowledges the U.S. Government's right to retain a nonexclusive, royalty-free license in and to any copyright covering this paper, along with the right to reproduce and to authorize others to reproduce all or part of the copyrighted paper. 


\section{DISCLAIMER}

This report was prepared as an account of work sponsored by an agency of the United States Government. Neither the United States Government nor any agency thereof, nor any of their employees, makes any warranty, express or implied, or assumes any legal liability or responsibility for the accuracy, completeness, or usefulness of any information, apparatus, product, or process disclosed, or represents that its use would not infringe privately owned rights. Reference herein to any specific commercial product, process, or service by trade name, trademark, manufacturer, or otherwise does not necessarily constitute or imply its endorsement, recommendation, or favoring by the United States Government or any agency thereof. The views and opinions of authors expressed herein do not necessarily state or reflect those of the United States Government or any agency thereof.

This report has been reproduced directly from the best available copy.

Available to DOE and DOE contractors from the Office of Scientific and Technical Information, P.O. Box 62, Oak Ridge, TN 37831; prices available from (615) 576-8401.

Available to the public from the National Technical Information Service, U.S. Department of Commerce; 5285 Port Royal Road, Springfield, VA 22161. 


\section{DISCLAMMER}

Portions of this document may be illegible in electronic image products. Images are produced from the best available original document. 


\title{
Report on Bioventing of Petroleum Contaminated Soils at 108-3C: Active Extraction and Passive Injection (Barometric Pumping) of a Gaseous Nutrient
}

\author{
J.R. Kastner, K. Lombard, J. Radway, J. Santo Domingo, \\ T.C. Hazen, and G.L. Burbage \\ Westinghouse Savannah River Co. \\ Biotechnology Group \\ Building 704-8T, Aiken SC 29808
}

\begin{abstract}
A bioventing system was constructed with horizontal extraction wells and vertical injection wells in an area which had previously been excavated and then backfilled. Initial in-situ respiration rates (air addition only) suggest that hydrocarbon degradation may be nutrient limited. The rate of TPH degradation was maximum (0.8-1.2 mg/kg/day) between $10-15 \mathrm{ft}$ (bgs), but dropped to essentially zero $30 \mathrm{ft}$ (bgs) within the contaminated zone (even though previous analysis at this depth indicated a TPH concentration of $3800 \mathrm{ppm})$. Analysis of the soil at $17 \mathrm{ft}$ showed that $\mathrm{NO}_{3}$ and $\mathrm{PO}_{4}$ were below detection limits $(0.5 \mathrm{ppm})$, indicating that nutrient limitation may be occurring. Nitrate levels were highest at $10 \mathrm{ft}$ (bgs), correlating with the highest respiration rates. However, phosphate levels were at/or below detection levels throughout the site (indicating possible $\mathrm{PO}_{4}$ limitation). Viable cells increased from $3 \times 10^{6} \mathrm{cfu} / \mathrm{g}$ at $3 \mathrm{ft}$ (bgs) to $1 \times$ $10^{7} \mathrm{cfu} / \mathrm{g}$ at $10 \mathrm{ft}$ (bgs) and remained relatively constant down to $17 \mathrm{ft}$. Cell numbers in the control area were significantly lower than in the contaminated zone $\left(4.5 \times 10^{3}\right)$. Gas phase nutrients (triethlyphosphate and nitrous oxide) will be injected to see if the hydrocarbon degradation rate can be increased.
\end{abstract}

\section{INTRODUCTION}

Since the 1950's, emergency power required for operation of Savannah River Site (SRS) Reactors has been met by diesel generator operations. These diesel engines were fueled via a system of above ground storage tanks (AST) in each Reactor Area (the 108-3 facilities K,L, and C). Past operating practices at these AST facilities resulted in the accumulation of diesel spillage for over 30 years.

In 1994, efforts to mechanically remove petroleum contaminated soils (PCS) found at the 108$3 \mathrm{C}$ AST site began. Following excavation down to 20 feet, in which approximately 500 cubic yards of contaminated soils were removed, several hand augured samples were taken at the bottom of the excavation pit. Extensive hydrocarbon contamination down to $>40 \mathrm{ft}$. was found 
(up to $3800 \mathrm{ppm}$ ) and mechanical removal was terminated since costs for removal would significantly exceed originally estimates. The operating history of the $108-3 \mathrm{~K}$ and $108-3 \mathrm{~L}$ AST sites, which were typical to $108-3 \mathrm{C}$, suggested that contamination at these sites would be similar to that discovered at 108-3C. Further characterization was performed at these sites using laser induced fluorescence probing (LIF) and cone penetrometer technology (CPT). With these technologies one site was determined to be clean $(108-3 \mathrm{~K})$ and at the other a hydrocarbon plume was characterized (108-3L, TPH up to $3600 \mathrm{ppm}$ ). Based on data from the literature, site characterization data, and sOILS facility data at SRS, bioventing was proposed as an economical clean-up method.

Several technologies developed at the SRS have been implemented in these bioventing projects; gas phase nutrient addition, discrete zone piezometers, and passive air injection via a Baro-Ball. Bioventing systems installed and operated at these sites each utilize a vacuum pump to pull air (oxygen) through the vadose zone. At Site 108-3C, horizontal extraction wells were installed during backfilling and passive injection wells were installed around the pit. The injection wells were connected to a diffusion chamber and Baro-Ball. The diffusion chamber will be half filled with triethylphosphate (TEP), a volatile organic phosphate, which will act as a gaseous source of phosphate. The Baro-Ball will act as a check valve to allow air flow through the tank and sweep TEP into the subsurface, but prevent backflow in the system if the vacuum pump fails or is shut down for in-situ respiration studies. The bioventing design at site $108-3 \mathrm{~L}$ is similar except that vertical extraction wells will be installed.

\section{BACKGROUND}

Biodegradation of petroleum hydrocarbons by stimulation of indigenous soil microorganisms, sometimes called biostimulation, is a proven remediation technology. Petroleum land farming has been used in the oil industry for decades to degrade large quantities of oil sludges (Bartha and Bossert, 1984). If adequate amounts of moisture, oxygen, and nutrients are available, complete degradation of petroleum hydrocarbons can occur. The process exploits the ability of many indigenous soil microorganisms to completely metabolize petroleum hydrocarbons to generate new biomass. Biostimulation can be applied both above ground in prepared beds (biopiles) and below ground (in-situ) via bioventing. In each case it is imperative to identify the rate limiting steps, such as low microbial numbers, low moisture content, nutrient limitation, low oxygen concentration... ect, and design the system to eliminate these steps.

Oxygen mass transfer is usually the initial rate limiting step in the degradation of petroleum hydrocarbons below the ground. Bioventing is a method of increasing oxygen mass transfer by either air injection or vacuum extraction and is appropriate for sites where the contamination is deeper and/or more extensive, provided the soil is relatively porous. However, contrary to soil vapor vacuum extraction, flow rates are relatively low to prevent stripping, but high enough to enhance microbial metabolism (Hinchee et al., 1991). Bioventing also has the advantage of being able to be integrated into a strategy that includes intrinsic bioremediation, thereby further 
reducing the over all costs of the remediation. Bioventing has been used to remediate gasoline, diesel, and PAH contaminated soils (Miller, 1991).

In general, air (oxygen) is the only nutrient injected during a bioventing campaign (EPA, 1995). It has been reported that nutrients are not required in most field bioventing sites (Miller, 1990 and 1991). However, in many cases biodegradation can be limited by nutrient availability (once oxygen limitations have been overcome) and hence nutrient feed systems may have to be combined with the bioventing process (Breedveld et al., 1995; Brockman et al., 1995). A wide range of nutrients have been successfully used to enhance bioremediation at other sites.

Nitrogen has been successfully introduced into the terrestrial subsurface for biostimulation using ammonia, nitrate, urea, and nitrous oxide (USEPA, 1989, Bioremediation of hazardous waste sites workshop, CERI-89-11, Washington, DC). Phosphorus is naturally quite low in most environments and in terrestrial subsurface environments even if phosphorus concentrations are high it may be in a mineral form that is biologically unavailable, eg. apatite. Several inorganic and organic forms of phosphate have been successfully used to biostimulate contaminated environments (EPA, 1989). The Savannah River Technology Center has successfully shown that triethylphosphate or TEP can be added in gas form to stimulate bioremediation (Hazen et al, 1994, Lawerence et al., 1994). Thus, nutrients can be added as a gas in the air injection wells (ie., nitrous oxide, ammonia and TEP) or in liquid form via infiltration galleries or sprinkler systems. Liquid nutrients such as $\left(\mathrm{NH}_{4} \mathrm{NO}_{3}\right)$ have been added to contaminated soil via surface irrigation in biosparging processes (Lord et al., 1995) and are transported to the contaminated zone by percolation. Gas phase nutrient addition provides a more uniform and direct transport of nutrients to the contaminated zone and overcomes precipitation problems.

\section{EXPERIMENTAL DESIGN}

\section{Site Characterization}

Approximately $500 \mathrm{yd}^{3}$ of petroleum contaminated soil was removed from 108-3C (down to a depth of 20'), which ranged in TPH concentration from 56 to 3000 ppm (based on 19 samples with a mean value of $1122 \mathrm{ppm}$ ). Petroleum contamination was also found another $10 \mathrm{ft}$ below the pit ( $3800 \mathrm{ppm})$, but was found to diminish to very low levels $20 \mathrm{ft}$ below the pit (11 ppm). Additionally, lateral soil borings indicated contamination ranging from 90 to 900 ppm TPH (Fig. 1). Because of the extensive contamination below the bottom of the pit, further excavation was not performed. It was decided to back-fill the pit with the contaminated soil and use bioventing to degrade the TPH.

Analytical and Microbial Methods:

Soil samples were analyzed for total petroleum hydrocarbons (diesel fraction, TPH-D) via EPA 8015M (Weston, PA). Groundwater samples were analyzed for TPH-D and BTEX (EPA 8240) Viable cell counts (aerobic heterotrophs) were performed using spread plates on $1 \%$ PTYG medium (Balkwill, 1989) and were based on dry weights. Nitrogen $\left(\mathrm{NO}_{2}, \mathrm{NO}_{3}\right)$ and phosphate 
$\left(\mathrm{PO}_{4}\right)$ were extracted from the soil using water as the solvent and quantified using ion chromatography (Greenberg, et al., 1992). Soil gas samples were evacuated via instrument pumps or a diaphragm vacuum pump (twin-headed KNF Neuberger, $I N C$., $17 \mathrm{~L} / \mathrm{min}$ at 29.5 in $\mathrm{Hg}$ ) from discrete zone sampling ports (1'x 1' tri-lock threaded chamber with a slotted sample chamber and hollow chamber swaged to $1 / 8^{\prime}$ tubing). Oxygen was measured using an $\mathrm{O}_{2}$ analyzer (Teledyne Brown, Portable Oxygen Analyzer - 0-5\%,0-10\% and 0-25\%) and a LandTec (GEM 500); the LandTec was also used to measure $\mathrm{CO}_{2}$, static and differential pressure.

\section{FACILITY DESIGN}

First, eight passive injection wells were installed using CPT (2" ID and 45' deep with 10' of well screen) and were positioned around the pit as portrayed in Figure. The injection wells were located in such a manner as to provide air and nutrient flow to contact the lateral contamination and contamination below the bottom of the pit, as well as the back-filled soil. Next, 1 " ID piezometers were positioned within the pit before back filling. Piezometers 1 and 2 were $30^{\prime}$ in length and a sampling device was positioned at 10', 20', and 30' down (Fig. 1). Piezometers 3 and 4 were $20^{\prime}$ in length and a sampling device was positioned at 5',10', 15', and 20' down (Fig. 1). The sampling device was designed such that soil gas and pressure readings could be obtained without effect from other sample ports (the PVC sampling device was 1" in length and 3 " in diameter with female and male tri-lock threads on each end, a counter bore and thread and a 0.55 " opening for tubing connection, and a slotting sampling area). CPT technology was used to install three vadose zone piezometers outside the zone of contamination (piezometers 5,6 , and 7 on Fig. 1). These piezometers were screened at $10^{\prime}$ (\#5), 45' (\#6), and 20' (\#7). Once the piezometers were in place, the pit was back-filled. As the pit was back-filled, 10/10/10 fertilizer was spread over the soil; approximately $8,50 \mathrm{lb}$ bags of fertilizer were added to the soil. At certain points during back filling, a layer of corrugated ABS pipe with slots was positioned in the pit. One hundred feet of the corrugated pipe was snaked in the hole and connected by a tee. Straight PVC riser was connected at the tee and taken to the top of the pit. The corrugated pipe was positioned at three layers $10^{\prime}, 15^{\prime}$, and $20^{\prime}$ down. The last layer at $10^{\prime}$ consisted of two $100^{\prime}$ sections of corrugated pipe and two risers (Fig.1). The corrugated pipe was wrapped in burlap to prevent the soil from blocking the slots.

Each PVC riser (4") was connected to a tee and reduced to one inch pipe. One inch pipe from each riser was connected to a globe valve, elbowed to a flow meter, and teed into a manifold. The manifolded system was connected to a vacuum pump (Roots/Dresser, Rotary Lobe Blower with maximum allowable operating conditions of $5275 \mathrm{rpm}, 14^{\prime \prime} \mathrm{Hg}$ vacuum and $225^{\circ} \mathrm{F}$ ). The top of each tee was capped and NPT threads added for a sampling port and addition of a pressure reading device. Each injection well was connected to a 3 gallon hot-dog tank (1" connection), this was the air/gas outlet, and the inlet was connected to a barrel ball via $1 / 2$ " stainless steel tubing. The Baro-Ball was constructed of PVC and is essentially a check valve to allow air flow through the tank, but prevent any backflow should in-situ pressure become greater than atmospheric. The diffusion chamber will be half filled with triethylphosphate(TEP), which is 
volatile (vapor pressure of $0.27 \mathrm{mmHg}$ at $20^{\circ} \mathrm{C}$ ) and will be transported by air flow through the chamber into the injection well.

\section{RESULTS}

In-situ Respiration and Baseline Data

Before the vacuum pump was turned on, soil gas analysis was performed and soil samples were analyzed for nutrients and microbial numbers as a function of depth. Soon after start-up, soil gas analysis was performed to test the effect of the vacuum pump on $\mathrm{O}_{2}$ mass transfer. Baseline in-situ respiration tests were also performed. Soil gas analysis clearly showed that certain areas within the backfill were metabolically active, since oxygen concentrations had dropped to 6 to 10 $\%$ relative to the control piezometers (points outside the contaminated area), but increased to near atmospheric levels once the extraction was initiated. In-situ respiration studies showed that the rate of oxygen consumption ranged between 0.8 and $1.7 \%$ /day across the site (Fig. 2). The oxygen consumption rates were converted to estimated TPH degradation rates using a batch reactor design equation, assuming zero order with respect to hydrocarbon concentration, and using the stochieometry of hexane oxidation (Equation from EPA Bioventing Manual).

$$
\text { Equation 1: } \mathrm{k}_{\mathrm{b}}=(\mathrm{ko})(\phi)\left(\mathrm{dO}_{2}\right)(\mathrm{C})(0.01) / \rho_{\text {soil }}
$$

where,

$-\mathrm{rTPH}_{\mathrm{T}}=\mathrm{k}_{\mathrm{b}}=\mathrm{mg} \mathrm{TPH} / \mathrm{kg}$ soil $/$ day, $\mathrm{k}_{\mathrm{o}}=\% \mathrm{O}_{2} / \mathrm{day}$, $\phi \mathrm{a}=\left(\right.$ Gas-Filled Pore Volume) $=0.25 \mathrm{~cm}^{3}$ gas $/ \mathrm{cm}^{3}$ soil (assumed value) $\mathrm{dO}_{2}=1300 \mathrm{mg} \mathrm{O} / \mathrm{L}$ $\mathrm{C}=0.29 \mathrm{mg}$ Hexane consumed $/ \mathrm{mg} \mathrm{O} 2$ consumed $\rho_{\text {soil }}=1.4 \mathrm{~g} / \mathrm{cm}^{3}$ (assumed value)

Equation 1 can be derived from the heterogeneous batch reactor design equation

$$
\mathrm{dN}_{\mathrm{j}} / \mathrm{dt}=\mathrm{r}_{\mathrm{j}} \mathrm{W} \text {, }
$$

where $\mathrm{W}=$ weight of the catalyst (in this case the soil) and the oxidation reaction for hexane, a representative hydrocarbon, is

$$
\begin{gathered}
9.5 \mathrm{O}_{2}+\mathrm{C}_{6} \mathrm{H}_{14} \text { gives } 6 \mathrm{CO}_{2}+7 \mathrm{H}_{2} \mathrm{O} \\
\mathrm{aA}+\mathrm{bB} \text { gives } \mathrm{cC}+\mathrm{dD} \\
-\mathrm{rA}=\mathrm{a} / \mathrm{b}-\mathrm{rB} \text { or }-\mathrm{rO}_{2}=9.5-\mathrm{rB} \\
-\mathrm{rB}=\mathrm{b} / \mathrm{a}-\mathrm{rA} \text { or }-\mathrm{rHexane}=1 / 9.5-\mathrm{rO} 2=0.29\left(\mathrm{mgHexane} / \mathrm{mgO}_{2}\right)-\mathrm{rO}_{2}
\end{gathered}
$$

Thus,

$$
\text { -rHexane }=(0.29)-\mathrm{rO}_{2}=(0.29) \mathrm{dN}_{\mathrm{j}} / \mathrm{dt} 1 / \mathrm{W}
$$

Assuming zero kinetics 
Assuming a constant volume reactor

$$
\begin{gathered}
-\mathrm{r}_{2}=\left(\mathrm{U}_{\max } \mathrm{X} / \mathrm{Y}_{\mathrm{O} 2}\right) \mathrm{O}_{2} /\left(\mathrm{K}_{\mathrm{O} 2}+\mathrm{O}_{2}\right) \\
\text { if } \mathrm{O}_{2}>\mathrm{K}_{\mathrm{O} 2} \\
\text { then }-\mathrm{r}_{\mathrm{O}_{2}}=\mathrm{U}_{\mathrm{max}} \mathrm{X} / \mathrm{Y}_{\mathrm{O} 2} \\
-\mathrm{r}_{\mathrm{O}_{2}}=\mathrm{dN} \mathrm{N}_{\mathrm{j}} / \mathrm{dt} 1 / \mathrm{W} \\
\mathrm{C}_{\mathrm{O} 2}=\mathrm{N}_{\mathrm{O} 2} / \mathrm{V}
\end{gathered}
$$

$$
-\mathrm{r}_{2}=\left(\mathrm{dC} \mathrm{O}_{2} / \mathrm{dt}\right) \mathrm{V} / \mathrm{W}
$$

where,

$\mathrm{dC}_{\mathrm{O} 2} / \mathrm{dt}$ is the slope of the in-situ respiration test,

$\mathrm{W}=$ Volume of solids $\mathrm{X}$ Density of solids

$\mathrm{W}=\{(\mathrm{I}-\phi) \mathrm{V}\}$ (Bulk Density)

$\phi=$ void volume / total bed volume (total porosity)

$\mathrm{V}=$ the reactor volume or volume of the contaminated soil

$$
-\mathrm{r}_{\mathrm{O}_{2}}=\mathrm{dC}_{\mathrm{O} 2} / \mathrm{dt} 1 /(1-\phi)\left(\rho_{\text {soii }}\right)
$$

The estimated degradation rates appear to peak between 10' and $15^{\prime}$ bgs, with lower rates near the surface and deeper in the pile (Fig. 3). These rates tend to correlate with an increase in cell numbers and nutrient levels at these points (Fig. 4), as well as TPH concentrations within the soil. The TPH concentration ranged from $64.5 \pm 16(\mathrm{n}=4)$ at $5^{\prime}, 114.3 \pm 18(\mathrm{n}=4)$ at $10^{\prime}$, and $117 \pm$ $57(n=4)$ at $15-17^{\prime}$ (from a limited number of samples). Total viable counts were higher at 10' and 15', and $\mathrm{NO}_{3}$ levels were higher at these depths (Fig. 4). However, phosphate levels were low and ranged from 0-0.3 ppm regardless of the depth (2-17 ft: data not shown). Thus, in general, respiration rates increased with higher TPH concentration and nutrients, which in turn probably increased microbial counts within the soil.

\section{$\underline{\text { Performance Assessment }}$}

To asses bioventing at 108-3C, the site was divided into two zones: the volume of soil backfilled $\left(500 \mathrm{yd}^{3}\right)$ or zone 1 and the volume of soil beneath the backfill which was contaminated (approximately a 10' [depth] x 20' [wide] x 40' [length] volume or $8000 \mathrm{ft}^{3}$ ) or zone 2 (see drawing below). The initial TPH concentration in zone 1 was assumed to be a mean value of $1100 \mathrm{ppm}$. Zone 1 appears to have been remediated close to acceptable levels (100 $\mathrm{ppm}$ ), based on the limited number of sample taken from the area. A method to estimate the final sample size to verify clean-up for zone 1 is shown below. 


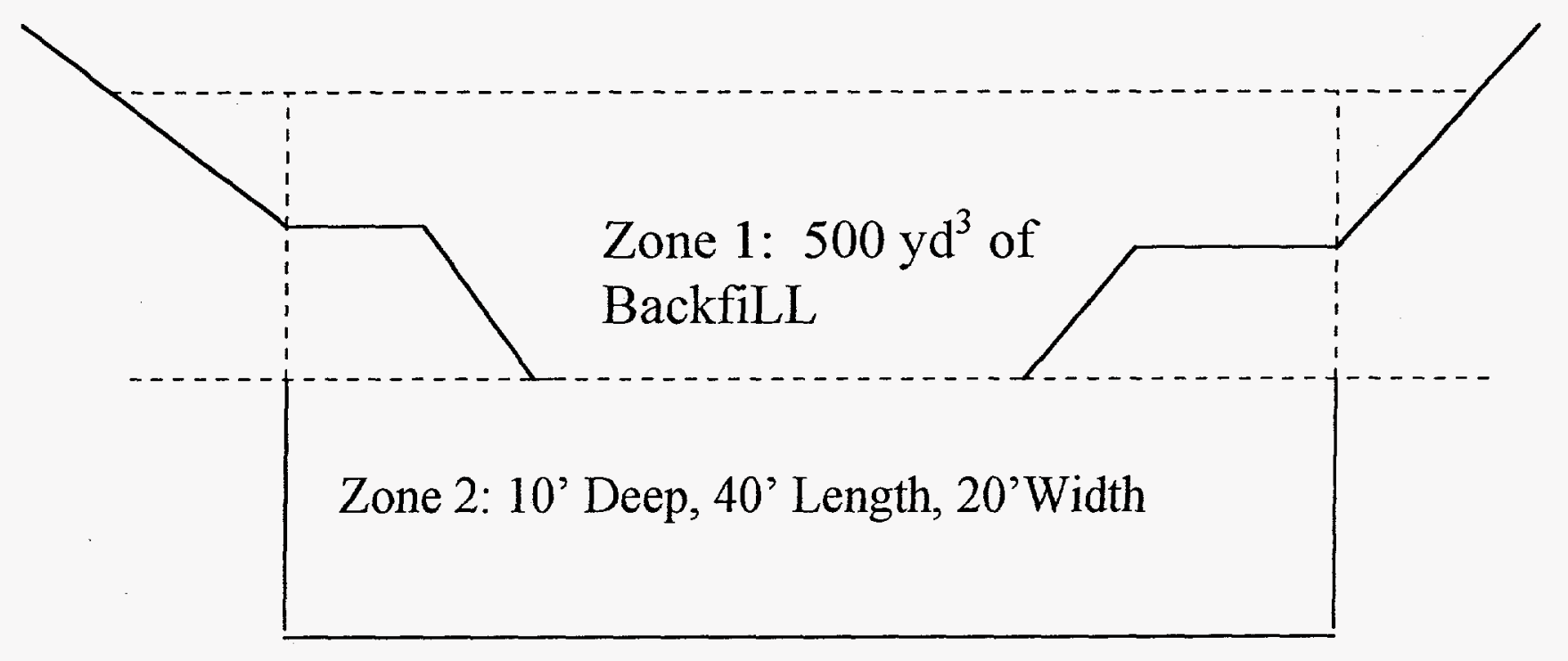

UCL (Upper Confidence Limit) $=X+(t=0.95(n-1)) S x$

where:

$\mathrm{n}=8$, number of samples

$\mathrm{Sx}=$ standard error $=\mathrm{S} / \mathrm{sqrt}(\mathrm{n})$

$S=$ standard deviation

$X=115.75$ (ignoring samples taken at 5')

$$
\mathrm{UCL}=115.75+(1.895 * 39.1 / 2.82)=142
$$

Since the UCL is above the maximum allowable concentration of $100 \mathrm{ppm}$ the lamba calculation is performed.

where:

$$
\lambda=(\mathrm{RT}-\mathrm{X}) / \mathrm{S}
$$

$\mathrm{RT}=$ regulatory limit

$\mathrm{S}=$ standard deviation

$$
\lambda=\operatorname{abs}(100-116) / 39.1=0.41
$$

From statistics tables $(\alpha=0.05$ and $\beta=0.05), 70$ more samples are required to verify the TPH concentration in zone 1 . Instead of continued sampling at the site, it is suggested that treatment continue and concentrate on zone 2 . Estimates of degradation rates within zone 1 will be used to approximate the time required clean-up. 
There are two sets of data that can be used to estimate the rate of TPH removal within zone 2: in-situ respiration rates and actual TPH analysis of the soil. The maximum rate of TPH removal based on in-situ respiration rates was measured at $1.2 \mathrm{mg} / \mathrm{kg} /$ day. However, if the change in TPH concentration is used, a higher rate is calculated. The batch reactor design equation was used to estimate the degradation rate in the following manner.

$$
\begin{aligned}
& -r_{A}=-\frac{d C_{A}}{d t}(\text { constant-volume }) \\
& -r_{A}=k C_{A}=k(\text { zero }- \text { order }) \\
& k=\int_{C_{A o}}^{C_{A(t)}} \frac{d C_{A}}{d t}=\frac{C_{A o}-C_{A(t)}}{t} \\
& t=N_{A o} \int_{0}^{X(t)} \frac{d X}{V\left(-r_{A}\right)}
\end{aligned}
$$

Using the third equation in the set above, the zero order rate constant, $\mathrm{k}$ ( $\mathrm{mg} / \mathrm{kg}$ soil/day) was estimated. The initial TPH concentration, $C_{A 0}$ was assumed to $1100 \mathrm{ppm}(\mathrm{mg} / \mathrm{kg})$, the final concentration, $C_{A}$, was assumed to be $116 \mathrm{ppm}$, and the total operating period was estimated at 8 months (240 days, which includes the time from backfilling to sampling). The rate constant, was found to be $4 \mathrm{mg} / \mathrm{kg} / \mathrm{day}$, approximately 4 times higher than those recently measured by in-situ respiration.

Using a rate of $4 \mathrm{mg} / \mathrm{kg} / \mathrm{day}$, several clean-up scenarios are projected for zone 2 . First, the third equation in the above set was rearranged and solved for $\mathrm{C}_{\mathrm{A}(\mathrm{t})}$ and the cumulative $\%$ conversion calculated for zone 2. Assuming an initial concentration of $3800 \mathrm{ppm}$, it would take approximately 2-3 years to reach $100 \mathrm{ppm}$ (Table 1 ). However, if the average TPH concentration for zone 2 is used $(3800,1000,290$; Mean $=1700)$ the required clean-up time is much shorter - 1 year (Table 2).

\section{CONCLUSIONS}

The estimated maximum degradation rate is relatively lower than rates reported for other diesel bioventing sites, $1-2 \mathrm{mg} / \mathrm{kg} /$ day compared to $6-30 \mathrm{mg} / \mathrm{kg} /$ day (EPA, 1995). The low rates could be due to many factors, such as low TPH concentration and low nutrient concentrations. A significant amount of degradation could have occurred in the excavated soil during storage and during the backfilling process when fertilizer was added to the soil, since in-situ respiration studies were performed 8 months after backfilling and installation of the biosystem. Recently, 
soil samples taken at $10^{\prime}$ and $15^{\prime}$ show that the TPH levels have declined from $1100 \mathrm{ppm}$ to 100 $180 \mathrm{ppm}$.

However, the lower respiration rates at the deeper depths (20' to $\left.30^{\prime}\right)$ are probably due to nutrient limitation and not low TPH levels. This is indicated by the fact that the rate of TPH degradation was maximum between 10-15 ft (bgs), but dropped to essentially zero $30 \mathrm{ft}$ (bgs) within the contaminated zone, even though previous analysis at this depth showed a TPH concentration of $3800 \mathrm{ppm}$. Moreover, analysis of the soil at $17 \mathrm{ft}$ showed that $\mathrm{NO}_{3}$ and $\mathrm{PO}_{4}$ were below detection limits $(0.5 \mathrm{ppm})$, indicating that nutrient limitation may be occurring. For this reason the gaseous nutrient, triethylphosphate, will be injected into the pile. In-situ respiration rates will be periodically monitored to see if TEP will increase the respiration rate and hence the hydrocarbon degradation rate. Since the backfilled soil appears to be relatively clean (100-150 ppm), attempts will be made to concentrate nutrient injection in the soil beneath the bottom of the pit. Helium tracer analysis will be performed to measure the influence of each injection well. Clean-up for zone 2 (beneath the bottom of the pit) is estimated to take 1-3 years from the start of aeration.

\section{REFERENCES}

Breedveld, G. D., G. Olstad, T. Briseid, and A. Hauge. 1995. Nutrient demand in bioventing of fuel oil pollution. In: In Situ Aeration: Air Sparging, Bioventing and Related Remediation Processes (eds) R. E. Hinchee, R. N. Miller and P. C. Johnson. P. 391-399. Battelle Press, Columbus, Ohio.

Brockman, F. J., W. Payne, D. J. Workman, A. Soong, S. Manley, and T. C. Hazen. 1995. Effect of gaseous nitrogen and phosphorus injection on in situ bioremediation of a trichloroethylene-contaminated site. J Haz. Mat. 41:287-298.

Hazen, T. C., K. H. Lombard, B. B. Looney, M. V. Enzien, J. M. Dougherty, C. B. Fliermans, J. Wear, and C. A. Eddy-Dilek. 1994. Summary of In Situ Bioremediation Demonstration (Methane Biostimulation) Via Horizontal Wells at the Savannah River Site Integrated Demonstration Project. Proceedings Thirty-Third Hanford Symposium on Health and the Environment: In-Situ Remediation: Scientific Basis for Current and Future Technologies, p. 135-150 G. W. Gee and N. R. Wing (eds). Battelle Press, Columbus, OH.

Hinchee, R. E., D. C. Downey, R. R. Dupont, P. K. Aggarwal, and R. N. Miller. 1991.

Enhancing biodegradation of petroleum-hydrocarbons through soil venting. J. Haz. Mat. 27:315325.

Hinchee and Ong, "A Rapid In Situ Respiration Test for Measuring Aerobic Biodegradation Rates of Hydrocarbons in Soil." Journal of the Air and Waste Management, 1992. 
Lawrence et al., "In-Situ Bioventing for Environmental Remediation of Natural Gas Dehydrator Site: A Field Demonstration", Society of Petroleum Engineers 69th Annual Technical Conference, New Orleans, Sept 1994.

Lord et al., In Situ Air Sparging for Bioremediation of Groundwater and Soils, in In Situ Aeration: Air Sparging, Bioventing, and Related Remediation Processes, Hinchee et al., (eds), p. 121,1995

Miller, R. V., and J. S. Poindexter. 1994. Strategies and Mechanisms for Field Research in Environmental Bioremediation. American Academy of Microbiology.

Ong et al., "In-Situ Respirometry for Determing Aerobic Degradation Rates", in In-Situ Bioreclamation: Applications and Investigations for Hydrocarbon and Contaminated Site Remediation, Butterworth-Heinemann, eds., Hinchee and Olfenbuttel, 1990.

USEPA. 1989. Bioremediation of hazardous waste sites workshop. CERI-89-11. Washington, DC.

USEPA. 1995. Manual: Bioventing Principles and Practive Volume I: Bioventing Principles. EPA/540/R-95/534a., Washington, DC. 


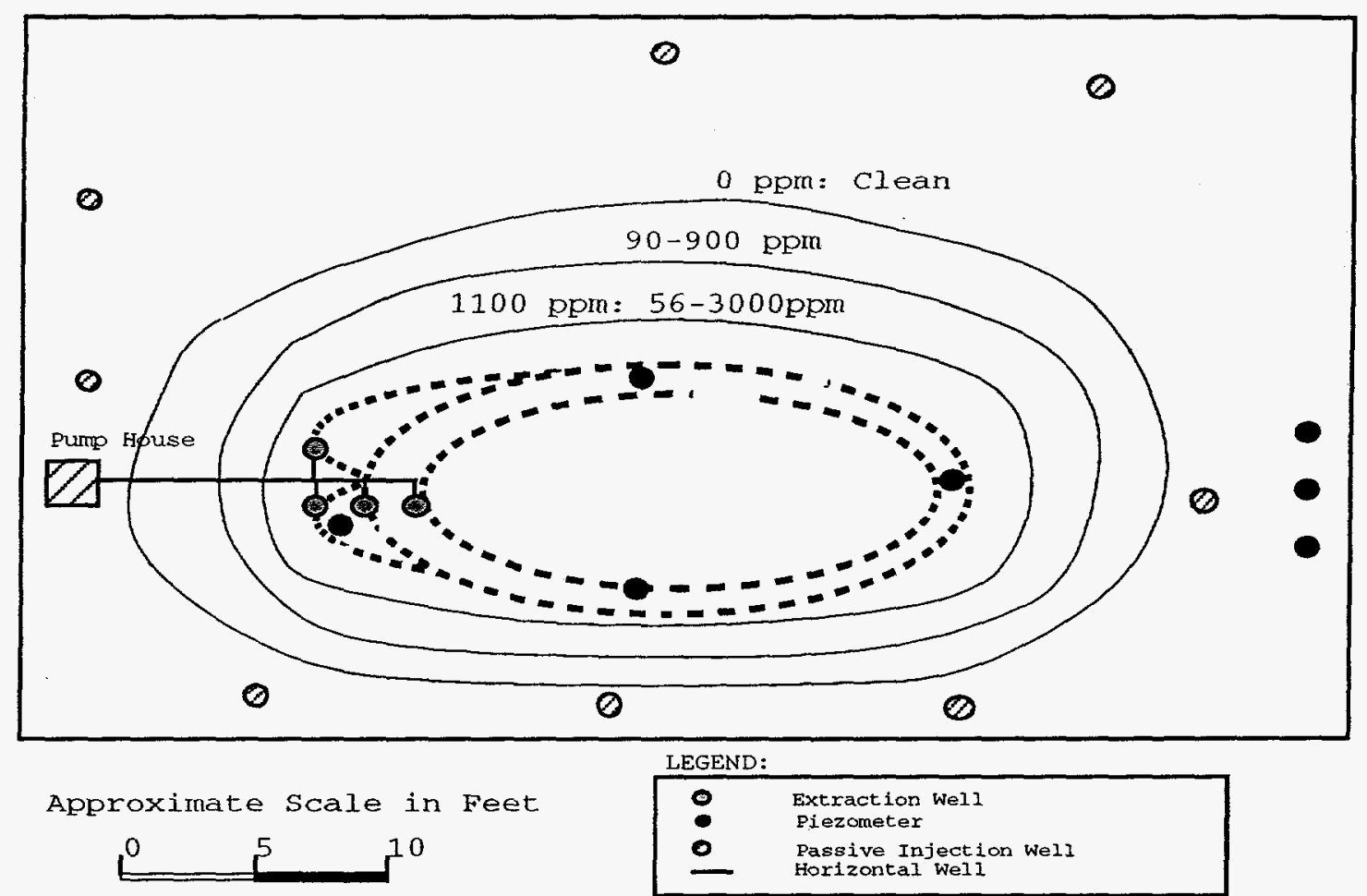

Figure 1 - Top view of site showing approximate location of injection wells, piezometers, extraction wells, approximate contour lines (horizontal), and horizontal wells. 

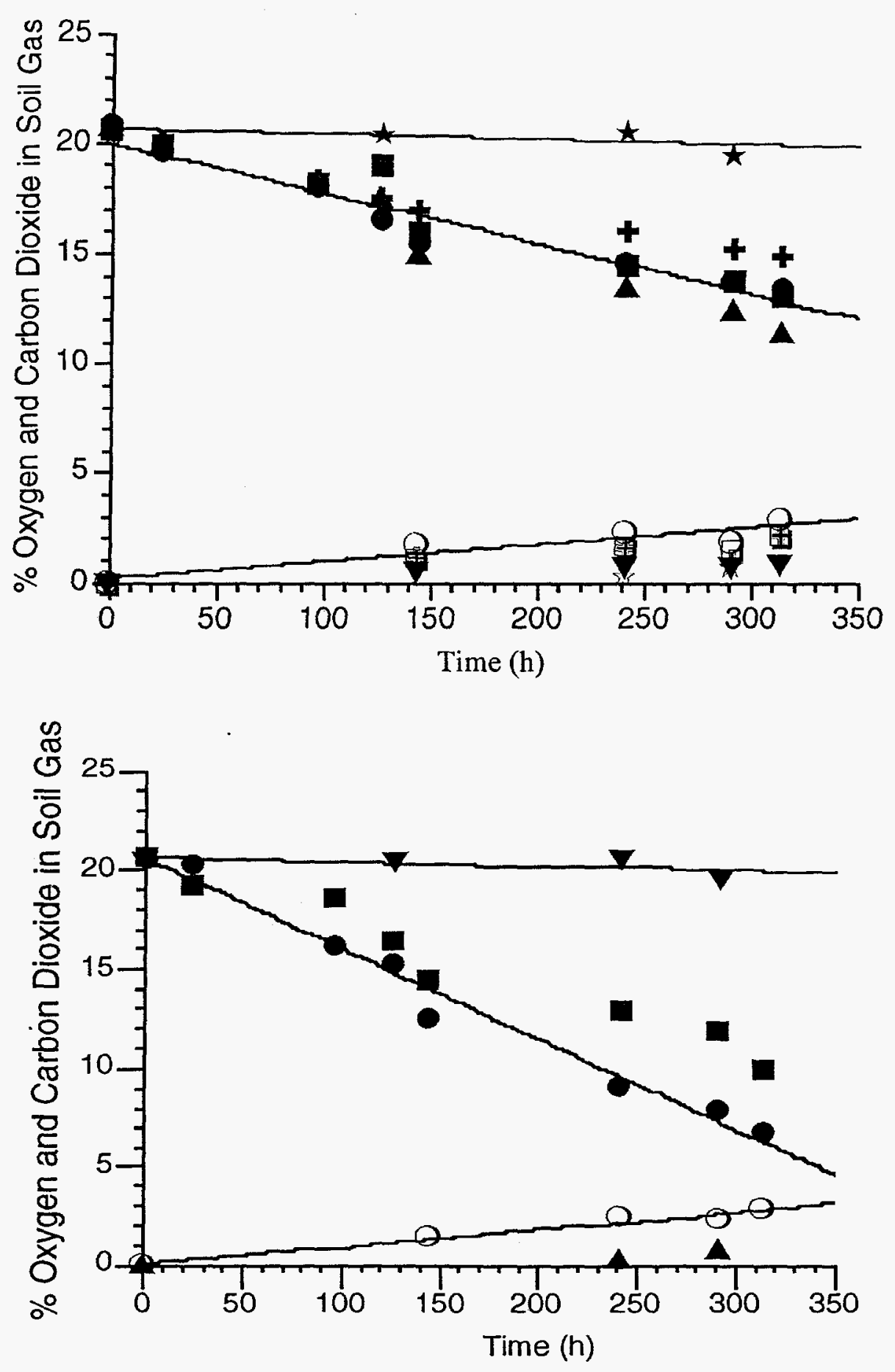

Figure 2: In-Situ Respiration rates at $10 \mathrm{ft}$ bgs(Top) and $15 \mathrm{ft}$ bgs (Bottom) After Shut Down of the Vacuum Extraction Pump: Oxygen Consumption $(\mathbf{\square , 0 ,}, \mathbf{+})$ and $\mathrm{CO}_{2}$ Production $\left(\square, O,\{\},\{)\right.$, Compared to a Control Piezometer Located Outside the Contaminated Zone $\left(\mathrm{O}_{2}, \boldsymbol{\nabla}\right.$; $\left.\mathrm{CO}_{2}, \mathbf{\Delta}\right)$. 


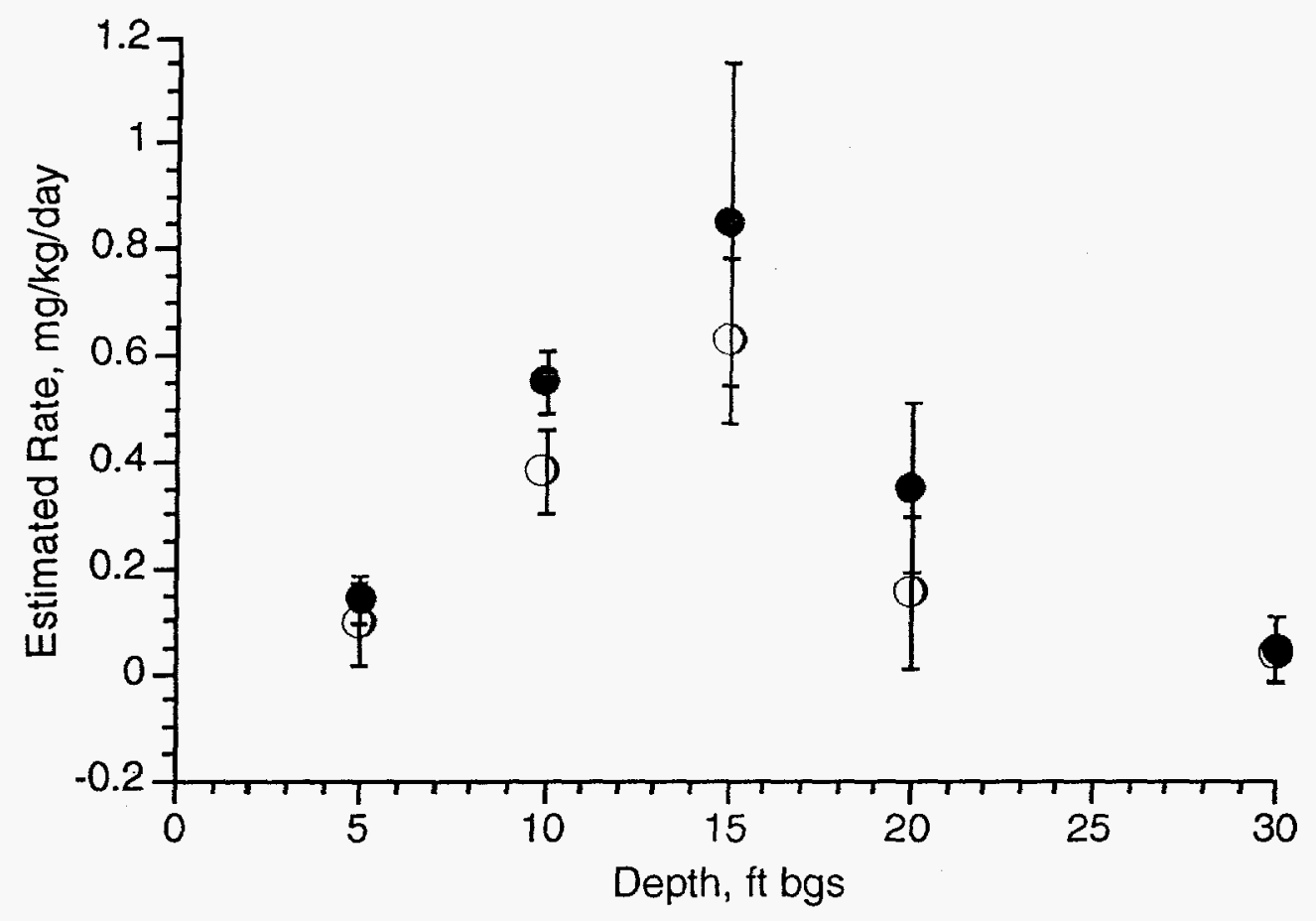

Figure 3: Change in the Estimated TPH Degradation Rate (Based on Slope of Oxygen Consumption Rates) as a Function of Depth Within the Contaminated Zone and Time: 6/96 and $8 / 96(\bullet)$ and $10 / 96(O)$. 
WSRC-RP-97-25

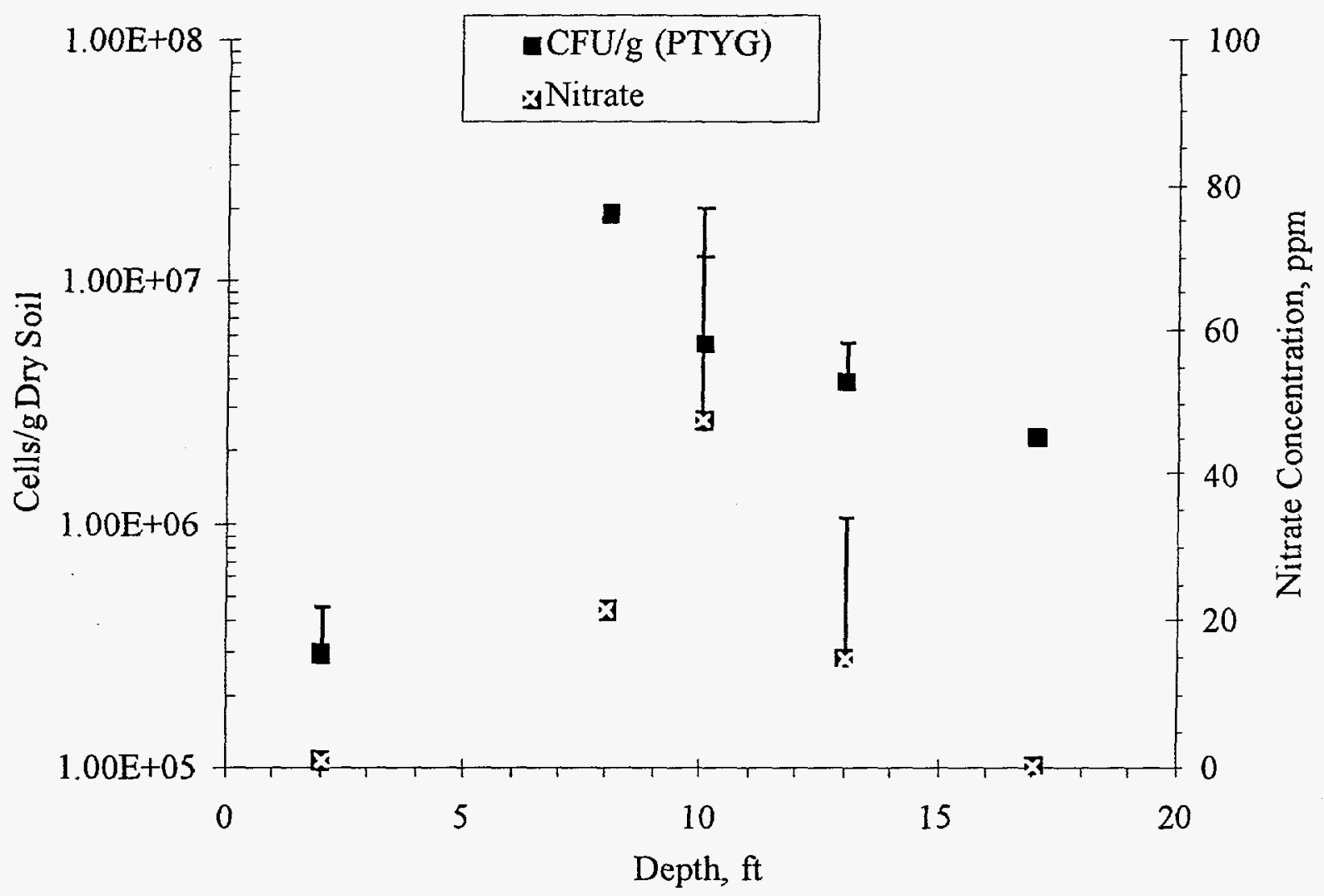

Figure 4: Viable Cell Count and Nutrient Concentration As A Function of Depth Within the Contaminated Zone. 
Table 1: Estimated Time Requirement for Clean-up at 108-3C (Zone 2)

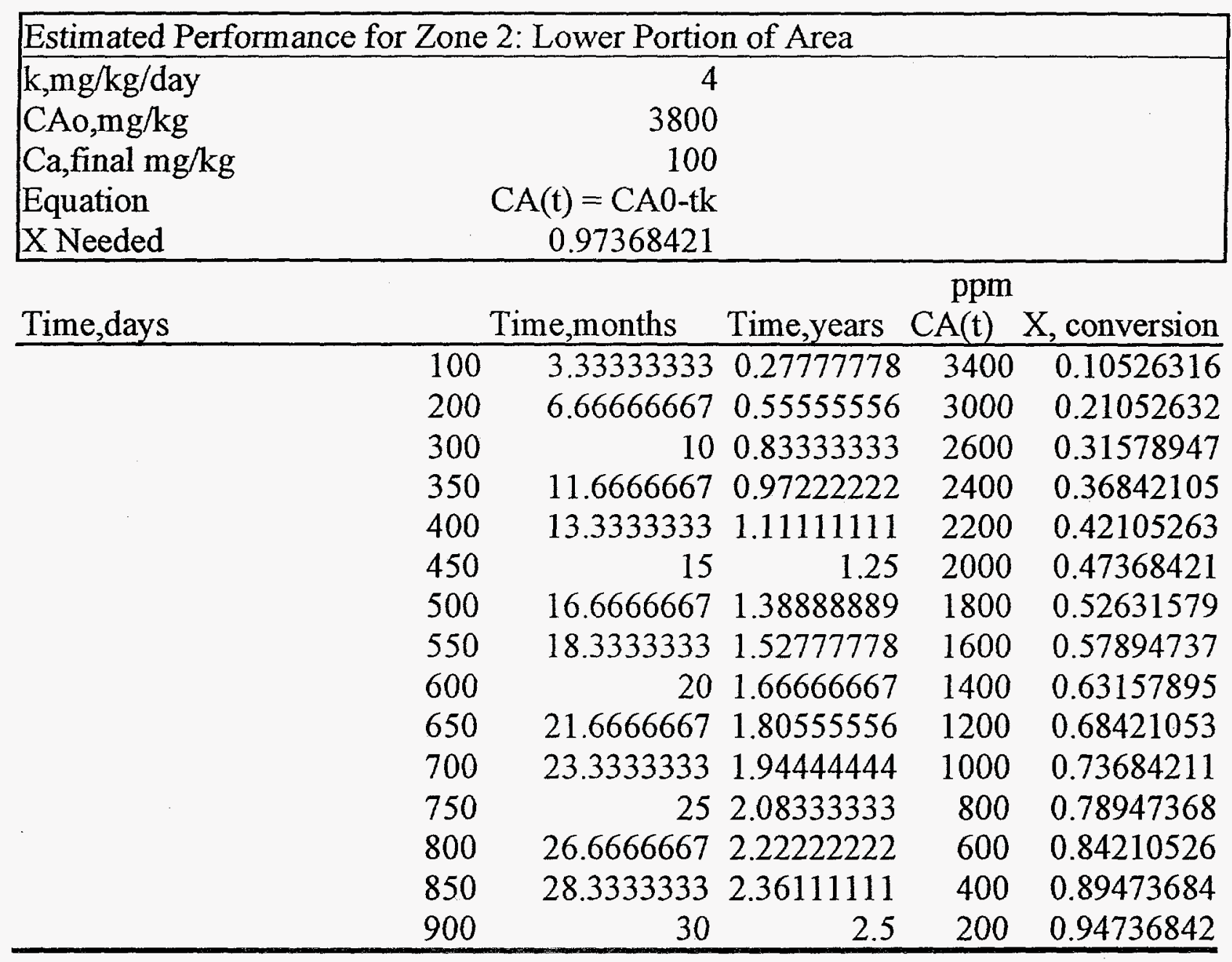


Table 2: Estimated Clean-up Time for Zone 2 at Site 108-3C

\begin{tabular}{|c|c|c|c|c|c|}
\hline \multicolumn{6}{|c|}{ Estimated Performance for Zone 2: Lower Portion of Area } \\
\hline \multirow{2}{*}{\multicolumn{6}{|c|}{$\begin{array}{lr}\mathrm{k}, \mathrm{mg} / \mathrm{kg} / \text { day } & 4\end{array}$}} \\
\hline CAo,mg $/ \mathrm{kg}$ & \multirow{2}{*}{\multicolumn{3}{|c|}{$\begin{array}{r}1700 \\
100\end{array}$}} & & \\
\hline $\mathrm{Ca}$, final $\mathrm{mg} / \mathrm{kg}$ & & & \\
\hline Equation & \multirow{2}{*}{\multicolumn{5}{|c|}{$\begin{array}{c}\mathrm{CA}(\mathrm{t})=\mathrm{CA} 0-\mathrm{tk} \\
0.97368421\end{array}$}} \\
\hline X Needed & & & & & \\
\hline \multirow[t]{6}{*}{ Time,days } & & months & Time,years & $\mathrm{CA}(\mathrm{t})$ & $\mathrm{X}$, conversion \\
\hline & 100 & 3.3333333 & 0.27777778 & 1300 & 0.65789474 \\
\hline & 200 & 6.6666666 & 0.55555556 & 900 & 0.76315789 \\
\hline & 300 & 1 & 0.83333333 & 500 & 0.86842105 \\
\hline & $350^{\circ}$ & 11.666666 & 0.97222222 & 300 & 0.92105263 \\
\hline & 400 & 13.333333 & 1.11111111 & 100 & 0.97368421 \\
\hline
\end{tabular}

